\title{
A Crumbled but Fatal Acute Leukemia
}

\author{
Parçalanmış ama Ölümcül Bir Akut Lösemi
}

\author{
(D) Francesco Tarantini1, (D) Cosimo Cumbo1, (D) Giorgina Specchia2, (D) Pellegrino Musto1, (D) Francesco Albano1 \\ 1 University of Bari "Aldo Moro," Hematology and Stem Cell Transplantation Unit, Department of Emergency and Organ Transplantation, Bari, \\ Italy \\ 2University of Bari "Aldo Moro," School of Medicine, Bari, Italy
}

\section{To the Editor,}

A 54-year-old woman was admitted to our center for progressive anemia and thrombocytopenia (white blood cells $4.9 \times 10^{9} / \mathrm{L}$, hemoglobin $96.8 \mathrm{~g} / \mathrm{L}$, and platelets $62.3 \times 10^{9} / \mathrm{L}$ ). She had a past medical history of metastatic breast cancer treated with surgery and adjuvant chemoradiotherapy 10 years before. A bone marrow (BM) biopsy showed hypercellular marrow with dysplastic features and $7 \%$ myeloid blasts. Cytogenetic analysis revealed a complex karyotype: $44, X_{1}-X_{1}$ ? del $(5 q), \operatorname{add}(6 p)_{1}-17$, $-20,+\operatorname{mar}[8][20]$. A diagnosis of therapy-related myelodysplastic syndrome (t-MDS) was made. The patient underwent four cycles of azacytidine, achieving hematologic recovery. A few weeks later, her blood cell count showed leukocytosis, anemia, and thrombocytopenia (white blood cells $18.1 \times 10^{9} / \mathrm{L}$, hemoglobin $92 \mathrm{~g} / \mathrm{L}$, and platelets $\left.62.0 \times 10^{9} / \mathrm{L}\right)$. Peripheral blood (PB) smear analysis showed several round, pale, basophilic fragments of cytoplasm (Figures 1A-1E, May-Grunwald-Giemsa, 100). BM aspiration showed many proerythroblasts ( $>60 \%$ of BM cells), often multinucleated (Figures 1F-1L, May-Grunwald-Giemsa, $100^{x}$ ), with basophilic fragmented and vacuolated cytoplasm. Moreover, proerythroblasts with marked cytoplasmic fracture lines were evident: large areas of basophilic cytoplasm were evident, separate from the contours of the nuclei, and basophilic fragments of cytoplasm of different sizes were visible (Figures 1F-1L, May-Grunwald-Giemsa, 100). The cytoplasm showed intense periodic acid-Schiff staining (Figure $1 \mathrm{M}$, periodic acidSchiff, 100x). Immunophenotype analysis by flow cytometry revealed that the BM cells were CD71+, CD235+, CD117+, CD34, and CD45-. Cytogenetic analysis could not be completed due to the absence of metaphases. Fluorescence in situ hybridization with a TP53 locus-specific probe revealed 17p chromosome deletion. A diagnosis of secondary pure erythroid leukemia (PEL) was made. The patient died a few days later. Next-generation sequencing (NGS) analysis was performed on BM samples at the time of the t-MDS diagnosis and then the PEL diagnosis. The entire coding regions or specific exons of 26 target genes (MPL, JAK2, CALR, DNMT3A, SF3B1, IDH1, IDH2, GATA2, KIT, TET2, NPM1, DDX41, ETV6, ANKRD26, EZH2, CBL, KRAS, NRAS, FLT3, SRSF2, CEBPA, ASXL1, RUNX1, ZRSR2, U2AF1, and TP53) were analyzed. NGS revealed the presence of TP53 gene mutation (p.R175H) in both samples. Considering the vacuolization in the cytoplasm of the erythroid cells, the UBA1 gene hotspot mutational status was evaluated, revealing no mutation.

PEL is characterized by cytological abnormalities of the proerythroblasts and basophilic erythroblasts that dominate the morphological picture (i.e., giant multinucleated forms, megaloblastic and markedly dysplastic nuclei, and abundant basophilic and vacuolated cytoplasm with frequent protrusions) [1]. There are many morphologic mimics of malignant proerythroblasts that could complicate the diagnosis of PEL. Our case showed all the morphological PEL anomalies and the presence of numerous basophilic cytoplasmic fragments in the $\mathrm{PB}$ and $\mathrm{BM}$, deriving from the breakdown of leukemic cells. These cytoplasmic fragments recall the lymphoglandular bodies often associated with lymphoid neoplasms [2]. The p.R175H TP53 gene mutation has been related to exuberant necroptosis in epithelial cells [3]. We cannot exclude the role of the p.R175H TP53 gene mutation in the cellular breakdown observed in our case.

Acknowledgments:This work was supported by the Associazione Italiana contro le Leucemie (AIL)-BARI.

Keywords: Pure erythroid leukemia, Cytoplasmic fragments, Therapy-related myeloid neoplasms, Necroptosis

Anahtar Sözcükler: Saf eritroid lösemi, Sitoplazmik parçalar, Tedavi ilişkili myeloid neoplaziler, Nekroptoz 


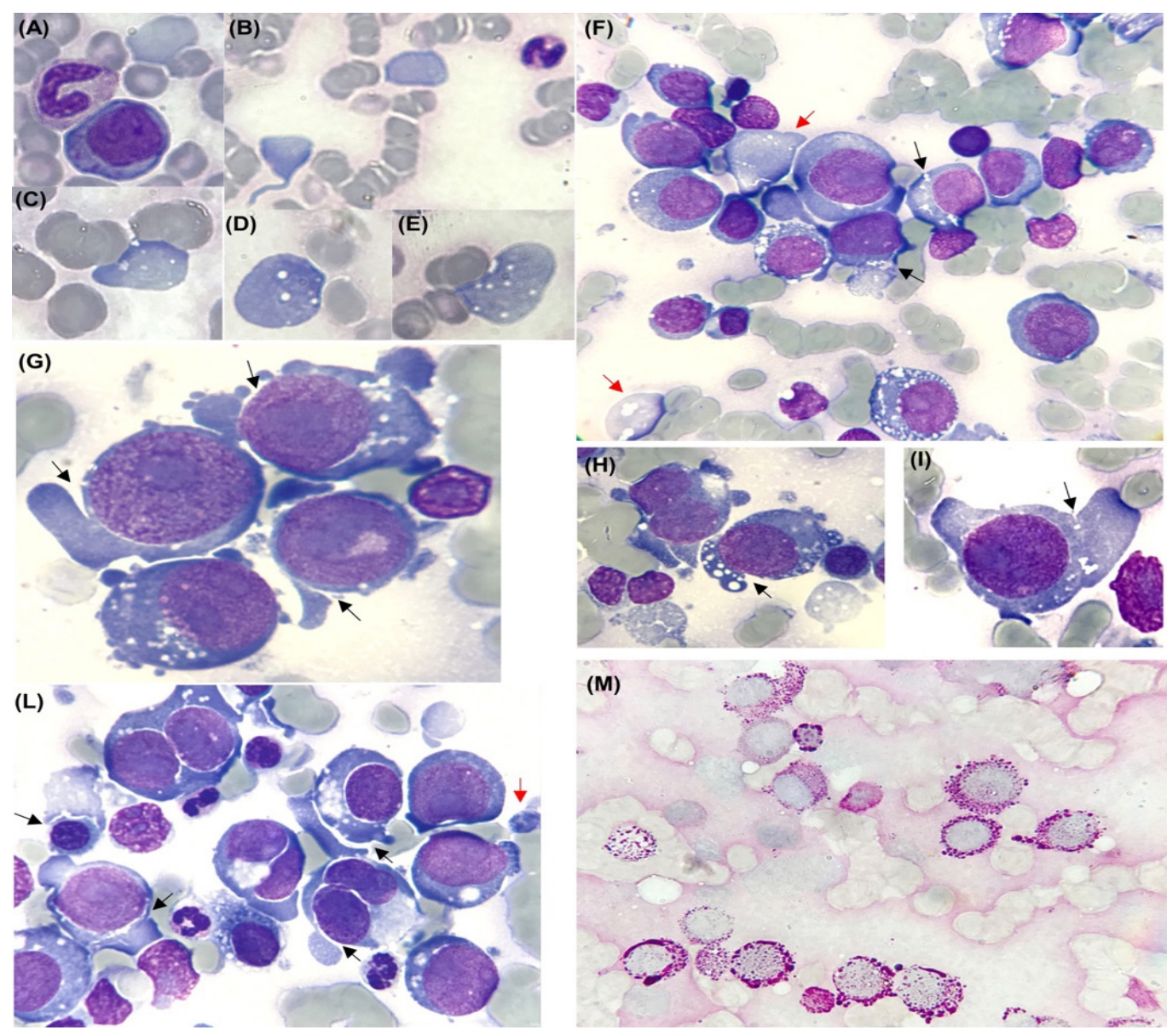

Figure. 1. A-E) Several round basophilic cytoplasm fragments of different sizes were observed in the peripheral blood smear (MayGrunwald-Giemsa, 100). F-L) Proerythroblasts and erythroid leukemic cells showed marked cytoplasmic fracture lines with large areas of basophilic cytoplasm, separate from the contours of the nuclei (black arrow), with evident basophilic fragments of cytoplasm of different sizes (red arrow) (May-Grunwald-Giemsa, 100). M) The cytoplasm of the erythroid leukemic cells showed intense periodic acid-Schiff staining (periodic acid-Schiff, 100×).

\section{Informed Consent: Obtained.}

\section{Authorship Contributions}

Concept: F.T., C.C., G.S., P.M., F.A.; Design: F.T., C.C., G.S., P.M., F.A.; Data Collection or Processing: F.T., C.C., G.S., P.M., F.A.; Analysis or Interpretation: F.T., C.C., G.S., P.M., F.A.; Literature Search: F.T., C.C., G.S., P.M., F.A.; Writing: F.T., C.C., G.S., P.M., F.A.

Conflict of Interest: No conflict of interest was declared by the authors.

Financial Disclosure: The authors declared that this study received no financial support.

\section{References}

1. Coccaro $N$, Zagaria $A$, Orsini $P$, Anelli $L$, Tota $G$, Casieri $P$, Impera $L$, Minervini A, Minervini CF, Cumbo C, Parciante $E$, Mestice A, Delia M, Brunetti C, Specchia G, Albano F. RARA and RARG gene downregulation associated with $E Z H 2$ mutation in acute promyelocytic-like morphology leukemia. Hum Pathol 2018;80:82-86.

2. Swerdlow SH, Campo E, Harris NL, Jaffe ES, Pileri SA, Stein H, Thiele J (eds). WHO Classification of Tumours of Haematopoietic and Lymphoid Tissues. Lyon, International Agency for Research on Cancer, 2017.

3. Stern RC, Liu K, Dodge RK, Elenitoba-Johnson KS, Layfield ப. Significance of lymphoglandular bodies in bone marrow aspiration smears. Diag Cytopathol 2001;24:240-243.

4. Watanabe $H$, Ishibashi $K$, Mano $H$, Kitamoto $S$, Sato $N$, Hoshiba $K$, Kato M, Matsuzawa F, Takeuchi Y, Shirai T, Ishikawa S, Morioka Y, Imagawa T, Sakaguchi K, Yonezawa S, Kon S, Fujita Y. Mutant p53-expressing cells undergo necroptosis via cell competition with the neighboring normal epithelial cells. Cell Rep 2018;23:3721-3729. 